\title{
PENGARUH KEAKTIFAN BELAJAR \& KECERDASAN EMOSIONAL TERHADAP PRESTASI BELAJAR MAHASISWA
}

\author{
(Studi Pada Program Studi Pendidikan Akuntansi Fakultas Keguruan \& \\ Ilmu Pendidikan Universitas Banten Jaya)
}

\author{
Oleh: 1. Nely Hartika, 2. Farach Mariana \\ Universitas Banten Jaya \\ Serang, Indonesia \\ Nely.hartika@gmail.com, farachmariana@unbaja.ac.id
}

\begin{abstract}
The purpose of this study was to determine 1) inflence of student learning activeness on learning achievement. 2) influence of emotional intelligence on learning achievement. 3) the influence of learning activeness \& emotional intelligence on learning achievement. This type of research is quantitative descriptive research. This study took place at the University of Banten Jaya, the Teaching and Education Faculty, majoring in Accounting. The population in this study were all students of the FKIP Accounting Education University of Banten Jaya, the population in this study were 84 students. Data collection techniques using questionnaire and docimentation techniques. The analysis technique used is multiple linear regression analysis. Test of the significance of multiple linear regression (Test $F$ ) and test the significance of multiple linear regression coefficients ( $t$ test), in addition to the calculation of relative donations and effective contributions. The results showed that 1) Learning activity did not have a significant influence on the learning achievement of Accounting Education students of Banten Jaya Faculty ofTeacher Training and Education which was indicated by table> thitung $(1,667>0,858)$. 2) Emotional Intelligence does not have a significant influence on the learning achievement of Accounting Education students of Banten Jaya Faculty of Teacher Training and Education which is indicated by table> thitung (1.667> 0.61) 3) Learning activity and intelligence together do not significantly influence the learning achievement of FKIP Accounting education students Banten Jaya University. Based on the F test, it is known that $\mathrm{HO}$ received by $\mathrm{Ha}$ is rejected because Fcount > Ftable (0.594>0.311) and the significance of significance of 0.05. That is 0.555.4) Student learning activeness variables contribute $6.25 \%$ effectively, students emotional intelligence variable contributes $6.1 \%$ effectively so the total contribution is $12.35 \%$, while the remaining $87.65 \%$ is influenced by other variables not examined.
\end{abstract}

Keyword : Learning Activities, Emotional Intelligence On Student Achievement

\section{PENDAHULUAN}

Pada era revolusi industri 4.0 dimana persaingan ketat telah terjadi baik dalam dunia industri maupun dunia pendidikan. Dunia pendidikan harus siap menghadapi tantangan yang terjadi.Salah satu upaya yang dilakukan adalah bagaimana meningkatkan prestasi belajar mahasiswa dengan berbagai pendekatan-pendekatan dalam pembelajaran. Kecakapan dan keaktifan mahasiswa sangatlah dituntut dan sangat menentukan tingkat prestasi belajar, mahasiswa harus merubah cara pandang dan cara berpikir. Sejalan dengan itu proyeksi pembelajaran abad 21 dimana empat kompetensi yang harus dimiliki 
oleh mahasiswa diantaranya: pertama mahasiswa harus bisa berpikir kritis,kreatif dan dapat mengungkapkan pendapatnya tanpa mendapat tekanan dari manapun berpikir secara rasional dan tidak mengedepankan emosi agar dapat bersaing, kedua mahasiswa harus bisa bekerjasama dalam hal networking (jaringan). sebab keberhasilan salah satunya dipengaruhi oleh jaringan.yang ketiga kompetensi yang diperlukan dalam pembelajaran abad 21 adalah kompetensi kemampuan berkomunikasi, keterampilan ini sangatlah penting untuk dapat meraih prestasi belajar yang tinggi. Kemampuan berkomunikasi juga diiringi dengan kemampuan teknologi atau istilah saat ini melek teknologi agar dapat bersaing pada era digital ini. Ke-empat kompetensi yang tidak kalah pentingnya yaitu berinovasi dalam kreativitas, agar dapat bertahan pada abad 21 ini. Didalam melaksanakan kegiatan pembelajaran terjadi dua kegiatan yang tidak dapat dihindari dan dua kegiatan yang bersinergi, yaitu dosen mengajar dan mahasiwa belajar. Keaktifan seorang mahasiwa dan pengalaman belajarnya dijadikan salah satu aspek perubahan dalam dirinya dari aspek kognitif, psikomotorik dan afektif.

Dosen yang kompeten yaitu dosen yang dapat menciptakan lingkungan

belajar yang aktif dan efektif. Dosen juga harus mempunyai kemampuan mengelola kelas dengan baik agar mahasiwa dapat belajar dengan baik.

Dosen dapat menggunakan berbagai model, metode, dan strategi yang dapat digunakan dosen untuk mengelola kegiatan pembelajaran agar lebih bervariasi. Namun hal tersebut belum dilakukan dosen secara optimal. Masih terbatasnya sumber daya manusia hingga terbatasnya sumber belajar yang dapat disediakan oleh sekolah membuat pembelajaran masih belum bervariasi dan aktif. Suasana belajar yang tidak kondusif serta pembelajaran yang monoton.

Kondisi pembelajaran yang seperti inilah yang membuat mahasiswa merasa bosan dan mengantuk dan pada ahirnya tidak fokus dan tidak dapat menerima dengan baik materi yang disampaikan. Mahasiswa cenderung tidak aktif dan lebih pasif, dosen juga kurang memiliki keterampilan dalam mengkolaborasi berbagai pendekatan dan metode mengajar. jika hal ini dibiarkan berlarutlarut maka prestasi belajar mahasiswa tentunya akan semakin rendah.

Rendahnya prestasi belajar
mahasiswa dapat disebabkan karena
belum terwujudnya mahasiswa aktif
belajar. "Keaktifan belajar siswa


merupakan persoalan penting dan mendasar yang harus difahami, dan dikembangkan setiap guru/dosen dalam proses pembelajaran sehingga keaktifan siswa perlu digali dari potensi-potensinya, yang mereka aktualisasikan melalui aktifitasnya untuk mencapai tujuan pembelajaran" (Aunurrahman, 2010:119)

Belajar aktif adalah "Metode pengajaran yang melibatkan siswa secara aktif dalam proses pembelajaran. Pembelajaran aktif mengondisikan agar siswa selalu melakukan pengalaman belajar yang bermakna dan senantiasa berpikir tentang apa yang dapat dilakukanya (Warsono dan Hariyanto, 2013: 12)"

Dari pendapat diatas dapat disimpulkan bahwa pembelajaran aktif adalah pembelajaran yang mengajak mahasiswa untuk selalu belajar aktif, pembelajaran dengan penuh semangat, hidup, giat, berkesinambungan, kuat dan efektif . dan dalam pembelajaran aktif mahasiswa harus aktif untuk berfikir logis, menerapkan ide-ide, memecahkan persoalan dan menanamkan konsep.

Menurut Sudjana (2010:61), Keaktifan belajar siswa dapat dilihat dari:
1) Partisipasi
aktif
dalam
melaksanakan
melaksanakan

tugas belajarnya

2) Terlibat dalam pemecahan masalah

3) Bertanya kepada siswa lain/kepada guru apabila tidak memahami persoalan yang dihadapinya

4) Berusaha mencari berbagai informasi yang diperoleh untuk pemecahan masalah

5) Melaksanakan diskusi kelompok Menilai kemampuan dirinya dan hasil yang diperolehnya

6) Melatih diri dalam memecahkan soal atau masalah

7) Kesempatan menggunakan/ menerapkan apa yang diperolehnya dalam menyelesaikan tugas/persoalan yang dihadapinya.

Dalam menyelesaikan tugas/ persoalan yang dihadapinya. Keaktifan mahasiswa sangat bervariasi, peran dosen lah untuk menjamin setiap mahasiswa untuk memperoleh pengetahuan dan keterampilan dalam kondisi yang ada. Dosen juga harus selalu memberi kesempatan bagi mahasiswa untuk bersikap aktif mencari, memperoleh, dan mengolah hasil belajarnya.

Keaktifan mahasiswa dalam proses pembelajaran dapat merangsang dan mengembangkan bakat yang dimilikinya, mahasiswa juga dapat berlatih untuk berfikir kritis dan dapat dipecahkan 
permasalahan-permasalahan dalam kehidupan sehari-hari. Disamping itu, Dosen juga dapat merekayasa sistem pembelajaran secara sistematis sehingga merangsang keaktifan mahasiswa dalam proses pembelajaran. Keaktifan dipengaruhi oleh beberapa faktor.

Menurut Gagne dan Briggs faktorfaktor tersebut diantaranya :

1) Memberikan dorongan atau menarik perhatian siswa, sehingga mereka dapat berperan aktif dalam kegiatan pembelajaran.

2) Menjelaskan tujuan intruksional (kemampuan dasar kepada siswa).

3) Mengingatkan kompetensi belajar kepada siswa.

4) Memberikan stimulus (masalah, topik dan konsep yang akan dipelajari).

5) Memberi petunjuk kepada siswa cara mempelajarinya.

6) Memunculkan aktivitas, partisipasi siswa dalam kegiatan pembelajaran.

7) Memberi umpan balik (feed back)

8) Melakukan tagihan-tagihan kepada siswa berupa tes, sehingga kemampua siswa selalu terpantau dan terukur.

9) Menyimpulkan setiap materi yang disampaikan di akhir pelajaran

Selain keaktifan belajar mahasiswa prestasi belajar mahasiswa juga dipengaruhi oleh kecerdasan secara pribadi. Gardner dalam bukunya yang berjudul Frames Of Mind mengatakan bahwa bukan hanya satu jenis kecerdasan yang monolitik yang penting untuk meraih sukses dalam kehidupan, melainkan ada spektrum kecerdasan yang lebar dengan tujuh varietas utama yaitu linguistik, matematika/logika, spasial, kinestetik, musik, interpersonal dan intrapersonal. Kecerdasan ini dinamakan oleh Gardner sebagai kecerdasan pribadi yang oleh Goleman disebut sebagai kecerdasan emosional (Goleman, 2012: $50) "$

"Kecerdasan pribadi terdiri dari: "kecerdasan antar pribadi yaitu kemampuan untuk memahami orang lain, apa yang memotivasi mereka, bagaimana mereka bekerja, bagaimana bekerja bahu membahu dengan kecerdasan. Sedangkan kecerdasan intra pribadi adalah kemampuan yang korelatif, tetapi terarah ke dalam diri. Kemampuan tersebut adalah kemampuan membentuk suatu model diri sendiri yang teliti dan mengacu pada diri serta kemampuan untuk menggunakan modal tadi sebagai alat untuk menempuh kehidupan secara efektif." (Goleman, 2012 : 52 )’”.

Dari Pendapat diatas dapat disimpulkan bahwa untuk meraih kesuksesan dalam hidup dengan tujuh 
varietas utama yaitu linguistik, matematika/logika, spasial, kinestetik, musik, interpersonal dan intrapersonal, kecerdasan ini dinamakan kecerdasan pribadi. kecerdasan pribadi terdiri dari memahami orang lain, memotivasi bagaimana mereka bekerja, bagaimana bekerja bahu membahu dengan kecerdasan. dan kecerdasan antar pribadi yaitu merupakan kunci menuju pengetahuan diri.

Goleman (2012:58-59) menempatkan kecerdasan pribadi Gardner dalam definisi dasar tentang kecerdasan emosional yang dicetuskannya dan memperluas kemampuan tersebut menjadi lima kemampuan utama, yaitu :

a. Mengenali Emosi Diri

Mengenali emosi diri sendiri merupakan suatu kemampuan untuk mengenali perasaan sewaktu perasaan itu terjadi. Kemampuan ini merupakan dasar dari kecerdasan emosional, para ahli psikologi menyebutkan kesadaran diri sebagai metamood, yakni kesadaran seseorang akan emosinya sendiri

Kesadaran diri adalah waspada terhadap suasana hati maupun pikiran tentang suasana hati, bila kurang waspada maka individu menjadi mudah larut dalam aliran emosi dan dikuasai oleh emosi. Kesadaran diri memang belum menjamin penguasaan emosi, namun merupakan salah satu prasyarat penting untuk mengendalikan emosi sehingga individu mudah menguasai emosi.

b. Mengelola Emosi

Mengelola emosi merupakan kemampuan individu dalam menangani perasaan agar dapat terungkap dengan tepat atau selaras, sehingga tercapai keseimbangan dalam diri individu. Menjaga agar emosi yang merisaukan tetap terkendali merupakan kunci menuju kesejahteraan emosi. Emosi berlebihan, yang meningkat dengan intensitas terlampau lama akan mengoyak kestabilan kita. Kemampuan ini mencakup kemampuan untuk menghibur diri sendiri, melepaskan kecemasan, kemurungan atau ketersinggungan dan akibat-akibat yang ditimbulkannya serta kemampuan untuk bangkit dari perasaan-perasaan yang menekan.

c. Memotivasi Diri Sendiri

Prestasi harus dilalui dengan dimilikinya motivasi dalam diri individu, yang berarti memiliki ketekunan untuk menahan diri terhadap kepuasan dan mengendalikan 
dorongan hati, serta mempunyai perasaan motivasi yang positif, yaitu antusianisme, gairah, optimis dan keyakinan diri.

d. Mengenali Emosi Orang Lain.

Kemampuan untuk mengenali emosi orang lain disebut juga empati. Kemampuan seseorang untuk mengenali orang lain atau peduli, menunjukkan kemampuan empati seseorang. Individu yang memiliki kemampuan empati lebih mampu menangkap sinyal-sinyal sosial yang tersembunyi yang mengisyaratkan apa-apa yang dibutuhkan orang lain sehingga ia lebih mampu menerima sudut pandang orang lain, peka terhadap perasaan orang lain dan lebih mampu untuk mendengarkan orang lain.

e. Membina Hubungan

Kemampuan dalam membina hubungan merupakan suatu keterampilan yang menunjang popularitas, kepemimpinan dan keberhasilan antar pribadi.

Keterampilan dalam berkomunikasi merupakan kemampuan dasar dalam keberhasilan membina hubungan. Individu sulit untuk mendapatkan apa yang diinginkannya dan sulit juga memahami keinginan serta kemauan orang lain.

Berdasarkan uraian tersebut di atas, dalam penelitian ini yang dimaksud dengan kecerdasan emosional adalah kemampuan siswa untuk mengenali emosi diri, mengelola emosi diri, memotivasi diri sendiri, mengenali emosi orang lain (empati) dan kemampuan untuk membina hubungan (kerjasama) dengan orang lain

Secara etimologis istilah prestasi merupakan kata serapan dan Bahasa belanda yaitu dari kata prestatie, yang biasa diartikan sebagai hasil usaha, atau suatu hasil yang telah dicapai, baik itu dilakukan ataupun dikerjakan, "dalam dunia pendidikan terdapat dua jenis prestasi, yaitu prestasi akademik dan prestasi belajar, prestasi akademik maksudnya adalah suatu hasil pelajaran yang diperoleh dari kegiatan sekolah yang bersifat kognitif (cognitive) dan biasanya melalui pengukuran dan penilaian. Adapun yang dimaksud dengan prestasi belajar adalah penguasaan pengetahuan atau keterampilan yang dikembangkan oleh suatu mata pelajaran yang lazimnya ditunjukan dengan nilai test atau angka nilai yang diberikan guru (Dikbud Dalam Heri Gunawan 2013:153).”

"Prestasi belajar adalah kecakapan nata atau aktual yang menunjukan kepada 
aspek kecakapan yang segera dapat didemostrasikan dan diuji karena merupakan hasil usaha yang bersangkutan dengan bahan dan dalam hal-hal tertentu yang dialaminya. Prestasi belajar adalah tingkat keberhasilan yang telah dicapai siswa dalam suatu kurun waktu proses belajar tertentu yang dapat diketahui dan hasil evaluasi yang dilaksanakan oleh guru (Syamsuddin Dalam Heri Gunawan 2013: 153)".

Berdasarkan pengertian tersebut di atas, maka dapat disimpulkan bahwa prestasi belajar adalah hasil belajar yang dapat dicapai oleh individu setelah melaksanakan serangkaian proses belajar. Ditingkat perguruan tinggi atau universitas prestasi belajar mahasiswa dinyatakan dengan indeks prestasi (IP). Tingkat keberhasilan studi yang dicapai oleh mahasiswa dari semua kegiatan akademik yang diikuti dalam jangka waktu tertentu yang dinyatakan dalam bentuk bilangan disebut Indeks Prestasi (IP).

Faktor-faktor yang mempengaruhi Prestasi belajar Secara umum menurut (Muhibbin Syah Dalam Gunawan 2013 : 157). Faktor-faktor yang mempengaruhi prestasi belajar siswa dapat dibedakan menjadi 3 macam yaitu : "(a) faktor internal (faktor dari dalam siswa) yakni keadaan/kondisi jasmani (aspek fisiologis) dan rohani siswa (aspek psikologis); (b) faktor eksternal (faktor dari luar siswa), yakni kondisi lingkungan.

\section{METODE PENELITIAN}

Metode yang digunakan dalam penelitian ini adalah metode penelitian Kuantitatif sedangkan dalam menganalisis data menggunakan statistik deskriptif.

Dalam penelitian ini yang menjadi subjek penelitian yaitu Mahasiswa Universitas Banten Jaya (UNBAJA). Teknik pengumpulan data penelitian ini dengan menggunakan angket dan kuesioner. Angket kuesioner berisi petunjuk pengisian angket kuesioner, identitas responden yang terdiri dari Nama, NPM, dan Semester, keterangan tentang pemberian skor dari setiap pertanyaan dan yang terakhir terdapat beberapa pertanyaan yang diajukan kepada responden. Populasi dalam penelitian ini adalah seluruh Mahasiswa Pendidikan Akuntansi Pada Fakultas Keguruan dan ilmu pendidikan Universtas Banten Jaya.

Teknik pengumpulan data yang digunakan dalam penelitian ini adalah sebagai berikut : angket, dokumentasi dan studi pustaka. Penelitian ini menggunakan instrumen berupa kuesioner (angket) yang memuat pertanyaan atau pernyataan 
tertulis yang diajukan kepada mahasiswa Fakultas Ilmu Keguruan dan Pendidikan Prodi pendidikan akuntansi Universitas Banten Jaya. Langkah-langkah sebagai berikut : Membuat Kisi-kisi Instrumen Instrument untuk mengungkap keaktifan belajar dan kecerdasan emosional menggunakan angket dengan skala Likert.

Uji coba instrumen dilakukan kepada Mahasiswa Pendidikan Akuntansi Fakultas Ilmu Pendidikan Akuntansi Universitas Banten Jaya dengan mengambil 84 responden yang tidak termasuk dalam sampel penelitian

\section{Uji Validitas}

Uji validitas digunakan untuk mengetahui kelayakan butir-butir dalam suatu daftar pertanyaan ini pada umumnya mendukung suatu kelompok variabel tertentu. Uji validitas sebaiknya dilakukan pada setiap butir pertanyaan di uji validitasnya. Hasil $\mathrm{r}$ hitung dibandingan dengan $r_{\text {tabel }}$ dimana $\mathrm{df}=\mathrm{n}-2$ dengan sig $5 \%$. bila $\mathrm{r}_{\text {tabel }}<\mathrm{r}_{\text {hitung }}$ maka valid. Pengukuran dilakukan dengan mengkorelasikan skor total setiap item dengan skor total seluruh item, dengan menggunakan teknik korelasi product moment pearson

a. untuk membuktikan antara dua variable berhubungan atau tidak dapat kita lihat kriteria sebagai berikut :
Jika $r_{\text {hitung }}>r_{\text {tabel }}$ (lihat tabel $r$ ) maka Ho ditolak

Jika $\mathrm{r}_{\text {hitung }}<\mathrm{r}_{\text {tabel }}$ (lihat tabel $\mathrm{r}$ ) maka Ha diterima

b. Melihat nilai koefisien korelasi merupakan nilai yang digunakan untuk mengukur kekuatan suatu hubungan antar variabel. Koefisien korelasi memiliki nilai antara -1 hingga +1 . Sifat nilai koefisien korelasi antara plus (+) atau minus (-).

\section{Uji Reliabilitas}

Reliabilitas (keandalan) merupakan ukuran suatu kestabilan dan konsistensi responden dalam menjawab hal yang berkaitan dengan kontruk-kontruk pertanyaan yang merupakan dimensi suatu variabel dan disusun dalam suatu benttuk kuisioner (V. Wiratna Sujarweni dan Poly Endrayanto, 2012 : 186). Uji reliabilitas dapat dilakukan secara bersama-sama terhadap seluruh butir pertanyaan.

Jika nilai Alpha > 0.60 maka relibel. Dengan rumus sebagai berikut :

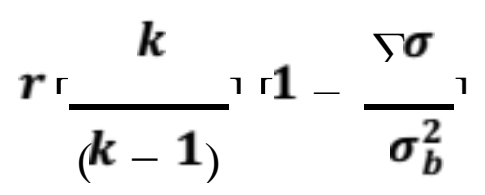

Dimana :

$\mathrm{r}=$ koefisien reliability instrument (Cronbach alfa)

$\mathrm{k}$ = banyak nya butir pertanyaan

$\sum^{\sigma}=$ total varians butir

$\sigma_{b}^{2}=$ total varians 


\section{Teknik Analisis Data}

\section{Analisis Deskriptif}

Analisis deskriptif adalah pengolahan data untuk tujuan mendeskripsikan atau memberi gambaran terhadap objek yang diteliti melalui data sampel atau populasi. Data yang diolah dalam statistisik deskriptif hanya satu variabel saja. Pada statistik deskriptif dapat menghasilkan tabel, grafik, diagram (V. Wiratna Sujarweni dan Poly Endrayanto, 2012 : 23). Hasil analisis deskriptif dalam penelitian ini akan disajikan dalam bentuk tabel dan diagram, hal ini dilakukan agar pembaca lebih mudah memahami.

2. Analisis Inferensial

Analisis inferensial dimaksudkan untuk mengambil kesimpulan dengan menguji hipotesis (V. Wiratna Sujarweni dan Poly Endrayanto, 2012 : 104).

Analisis inferensial digunakan untuk mengetahui hubungan kausalitas atau pengaruh antara variabel bebas terhadap variabel terikat.

a. Uji Prasyarat Analisis

1) Uji Normalitas

Uji normalitas digunakan untuk melihat normalitas model regresi, variabel residual memiliki distribusi normal. Distribusi normal akan membentuk garis diagonalnya (Gozali 2013: 160).
Pengujian dilakukan dengan analisi grafik plot atau uji non-parametrik One

Sample Kolmorov Smirnov Test. Pengambilan keputusan dilakukan dengan membandingkan $\mathrm{P}$ Value yang diperoleh dari hasil pengujian normalitas dengan tingkat signifikasi sebesar 0,05 data dikatakan terdistribusi secara normal jika probabilitas kurang dari 0,05 maka data yang dijadikam dalam penelitian ini tidak berdistribusi normal.

2) . Uji Linearitas

Uji ini digunakan untuk melihat apakah terjadi hubungan yang linier atau tidak antar variabel. Uji yang digunakan adalah uji Mean-Test for Linearity menggunakan SPSS. Dua variabel dikatakan mempunyai hubungan yang linear bila nilai signifikasi pada Linearity kurang dari 0,05 atau berdasar teori lain yaitu jika signifikasi pada Deviation from Linearity lebih dari 0,05 maka kedua variabel berhubungan secara linier Uji linearitas berfungsi untuk mengetahui hubungan antara dua variabel, yaitu ada atau tidaknya signifikasi keterkaitan variabel satu dengan yang lain, serta sifatnya linear atau tidak ( $V$. Wiratna Sujarweni dan Poly Endrayanto, 2012 : 104). Adapun rumus uji linearitas adalah sebagai berikut:

$$
\mathrm{Y}=\mathrm{a}+\mathrm{bX} 1
$$


Dimana :

$\mathrm{Y}=$ Variabel terikat

$\mathrm{X} 1=$ Variabel bebas

$\mathrm{a}=$ Kostanta intersep

$\mathrm{b}=($ slop/kemiringan $)$ koefisien

regresi $\mathrm{Y}$ atas $\mathrm{X}$ kembali

(Singgih Santoso 2012: 234).

Untuk mendektesi ada tidaknya multikolineritas dapat dilihat dari besaran variance inflation factor (VIF) dan tolerance. Suatu model regresi yang bebas multikolinearitas mempunyai pedoman dimana angka tolerance mendekati 1 . Batas VIF adalah 10, jika nilai VIF dibawah 10 , maka tidak terjadi Multikolinearitas.

b. Uji Hipotesis

Uji hipotesis yang dilakukan dalam penelitian ini dengan menggunakan analisis regresi. Dikarenakan dalam penelitian ini variabel bebas lebih dari satu variabel maka dilakukan analisis regresi linier berganda. Persamaan regresi linier berganda dalam penelitian ini dapat diformulasikan sebagai berikut:

$$
\mathrm{Y}=\mathrm{a}+\mathrm{b} 1 \mathrm{X} 1+\mathrm{b} 2 \mathrm{X} 2
$$

Keterangan:

$\mathrm{Y}=$ prestasi belajar mahasiswa

$\mathrm{a}=$ bilangan konstanta

b1= koefisien keaktifan belajar

b2 $=$ koefisien kecerdasan emosional

X1= keaktifan belajar

\section{$\mathrm{X} 2=$ kecerdasan emosional}

Berikut langkah-langkah dalam pengujian hipotesis:

1) Uji Parsial (Uji t)

Untuk menguji bagaimana pengaruh masing-masing variabel bebas secara sendiri-sendiri terhadap variabel terikat maka dilakukan uji t. Sehingga bisa diketahui diterima atau tidaknya hipotesis satu dan dua. Jika nilai sig kurang dari 0,05 maka dapat disimpulkan terdapat pengaruh yang signifikan dari masingmasing variabel bebas terhadap variabel terikat.

$\mathrm{Se}=\sqrt{ } \sum 2-\left(1 \cdot \sum 1+2 \cdot \sum 2.\right)$

$\sum 222=\sqrt{ }\left(\sum 12\right)\left(\sum 22\right)-\left(\sum 1.2\right) 2$

Mencari uji hipotesis apakah terdapat pengaruh antara $\mathrm{X} 1$ Terhadap $\mathrm{Y} \mathrm{t}_{\text {hitung }} 1=$ Ho : tidak terdapat pengaruh antara $\mathrm{X}$ 1terhadap Y

$\mathrm{Ha}$ : terdapat pengaruh antara $\mathrm{X} \quad 1$ terhadap Y

Mencari uji hipotesis apakah terdapat pengaruh antara $\mathrm{X} 2$ Terhadap $\mathrm{Y} \mathrm{t}_{\text {hitung }} 2=$ Ho : tidak terdapat pengaruh antara $\mathrm{X}$ 2terhadap Y

$\mathrm{Ha}$ : terdapat pengaruh antara X 2terhadap Y

2) Uji Simultan (Uji F)

Uji simultan dilakukan untuk mengetahui apakah variabel bebas secara 
bersama-sama berpengaruh terhadap variabel terikat oleh karenanya dilakukan uji F. Sehingga dapat mengetahui diterima atau tidaknya hipotesis ketiga. Apabila nilai sig $F$ kurang dari 0,05 maka disimpulkan bahwa variabel bebas secara bersama-sama berpengaruh signifikan terhadap variabel terikat. Rumus mencari uji serentak/silmutan

$\mathrm{F}:\left(\cdot \sum+\sum\right.$

Fhitung $=$ Kriteria :

Jika Fhitung $>$ Ftabel $=$ Ho ditolak

Jika Fhitung $<$ Ftabel $=$ Ho diterima

3) Mencari Koefisien Determinasi (R2)

Untuk melihat seberapa besar variabel-variabel bebas mampu memberikan penjelasan mengenai variabel terikat maka perlu dicari nilai koefisien determinasi (R2). Nilai R2 adalah antara nol dan satu $(0 \leq \mathrm{R} 2 \leq 1)$. Jika nilai $\mathrm{R} 2$ semakin mendekati satu, menunjukkan semakin kuat kemampuan variabel bebas dalam menjelaskan variabel terikat. Jika nilai R2 adalah nol, menunjukkan bahwa variabel bebas secara keseluruhan tidak dapat menjelaskan variabel terikat. Rumus mencari nilai koefisien determinasi

\section{HASIL PENELITIAN DAN PEMBAHASAN}

Penelitian ini menggunakan program aplikasi microsoft office excel 2016 dan
SPSS Versi 22, dari penelitian diatas maka dapat diketahui seberapa besar pengaruh keaktifan belajar dan kecerdasan emosinal terhadap prestasi mahasiswa pendidikan akuntansi pada fakultas keguruan dan ilmu pendidikan Universitas Banten Jaya, Kuesoner atau angket dibagikan kepada responden untuk mengetahui apa yang mempengaruhi prestasi belajar mahasiswa melaui keaktifan belajar dan kecerdasan emosional.

Dari hasil analisis data yang telah dilakukan dapat diketahui bahwa hasil penelitian ini menunjukan tidak ada pengaruh yang signifikan antara variabel keaktifan belajar dan kecerdasan emosional terhadap prestasi belajar mahasiswa Universitas Banten Jaya. Hal ini dibuktikan dari hasil perhitungan analisis statistik yang telah dilakukan dan diperoleh hasil demikian.

Pengaruh Keaktifan Belajar Terhadap Prestasi Belajar Mahasiswa pendidikan akuntansi pada Fakultas Keguruan dan Ilmu Pendidikan Universitas Banten Jaya

Dari hasil pengujian data yang dilakukan secara parsial menunjukan $t_{\text {tabel }}$ (1.66) $>0,858 t_{\text {hitung }}$ dan nilai probabilitas sebesar $0,393>0,05$. Maka dapat disimpulkan bahwa H0 diterima atau Ha ditolak. Dengan demikian, dapat 
disimpulkan bahwa secara sendiri-sendiri (Parsial) Keaktifan Belajar tidak berpengaruh terhadap prestasi belajar mahasiswa.

Temuan ini mengidentifikasi bahwa faktor-faktor lain dari keaktifan belajar yang lebih dominan dibandingkan dengan faktor keaktifan belajar, jika dilihat dari aspek metodologis, peneliti diberikan izin waktu membagikan dan menunggu pengisian angket yang sangat terbatas, diketahui pula pada saat mahasiswa mengisi angket peneliti melihat sendiri beberapa mahasiswa yang sembarangan dalam mengisi angket. Dan diketahui juga dari bentuk centang yang melenggaklenggok.

Meskipun keaktifan belajar bukan faktor dominan yang mempengaruhi prestasi belajar Mahasiswa, akan tetapi kecerdasan emosional tetap tidak boleh diabaikan begitu saja sebab kecerdasan emosional dapat mendukung faktor-faktor lain yang lebih dominan dan dapat menjadikan mahasiswa meningkatkan prestasi belajarnya Pengaruh Kecerdasan Emosional Terhadap Prestasi Belajar Mahasiswa pendidikan akuntansi pada Fakultas Keguruan dan Ilmu Pendidikan Universitas Banten Jaya Dari hasil pengujian data yang dilakukan secara parsial menunjukan $\mathrm{t}$ tabel $(1.66)>0,091$ $\mathrm{t}_{\text {hitung }}$ dan nilai probabilitas $0,928>0,05$, maka dapat disimpulkan bahwa H0 diterima $\mathrm{Ha}$ ditolak. Analisis tersebut membuktikan bahwasanya Kecerdasan Emosional tidak berpengaruh terhadap prestasi belajar terhadap prestasi belajar mahasiswa.

Dari hasil tersebut menunjukan bahwa kecerdasan emosioanl tidak mempunyai pengaruh terhadap prestasi belajar siswa. Meskipun kecerdasan emosional bukan faktor dominan yang mempengaruhi prestasi belajar Mahasiswa, akan tetapi kecerdasan emosional tetap tidak boleh diabaikan begitu saja sebab kecerdasan emosional dapat mendukung faktor-faktor lain yang lebih dominan dan dapat menjadikan mahasiswa meningkatkan prestasi belajarnya.

Pengaruh Keaktifan Belajar dan Kecerdasan Emosional Terhadap Prestasi Belajar Mahasiswa pendidikan akuntansi pada Fakultas Keguruan dan Ilmu Pendidikan Universitas Banten Jaya Prestasi belajar merupakan hal yang tidak dapat dipisahkan dari kegiatan belajar, karena kegiatan merupakan proses, sedangkan prestasi merupakan hasil dari belajar. Prestasi belajar siswa banyak dipengaruhi dari berbagai faktor, baik yang berasal dari siswa (internal) maupun 
dari luar diri siswa (eksternal). Faktor internal antara lain terdiri dari sikap, bakat minat intelegensi, kreativitas dan motivasi. Sebagian faktor eksternal terdiri dari lingkungan sekolah dan lingkungan non sosial, diantaranya adalah keluarga, sekolah dan masyarakat. Prestasi belajar adalah hasil yang dicapai oleh siswa selama berlangsungnya proses belajar mengajar dalam jangka waktu tertentu. Maka dalam penelitian ini prestasi belajar diambil dari nilai IPK Mahasiswa Fakultas Keguruan dan Ilmu Pendidikan prodi pendidikan akuntansi Universitas Banten Jaya.

Dari analisis pengujian yang dilakukan secara simultan menyatakan $\mathrm{F}$ hitung $0,594<3.11$ dengan nilai probabilitas $0,555>0,05$ sehingga ini menunjukan bahwa $\mathrm{HO}$ diterima $\mathrm{Ha}$ ditolak. Analisis tersebut membuktikan bahwasanya tidak ada pengaruh yang signifikan dari variabel Keaktifan Belajar dan Kecerdasan Emosional terhadap Prestasi belajar Mahasiswa.

Hal ini berarti menunjukkan bahwa kecerdasan emosional dan Keaktifan belajar yang baik tidak menjadikan prestasi belajar siswa meningkat Hasil tersebut dimungkinkan karena kondisi kecerdasan emosional siswa saat mengisi angket sedang dalam kondisi rendah dan kecerdasan emosional seseorang dapat berubah-ubah dipengaruhi oleh lingkungan sekitarnya.

Sehingga tidak berpengaruh terhadap prestasi belajarnya. Begitu juga dengan Keaktifan belajar siswa yang bersangkutan saat mengisi angket dimungkinkan dalam kondisi tidak bagus. Sehingga keaktifan belajar tidak berpengaruh terhadap prestasi belajar. Disini peneliti juga menemukan beberapa Mahasiswa yang sembarangan dalam mengisi angket yang diberikan. Sehingga dapat diduga dari situlah penyebab kedua variabel ini tidak mempengaruhi prestasi belajar. Disisi lain waktu yang tidak efektif saat membagikan angket yaitu ketika jam pelajaran mata kuliah berlangsung peneliti membagikan angket sedangkan saat itu kegiatan belajar mengajar sedang dilangsungkan oleh Dosen. Peneliti hanya diberikan sedikit waktu oleh dosen yang bersangkutan untuk memberikan kesempatan mahasiswanya menjawab angket dari peneliti. Hal ini berarti yang mempengaruhi prestasi belajar siswa dimungkinkan berasal dari faktor eksternal seperti lingkungan keluarga, keadaan keluarga, lingkungan sekolah (teman sekolah, guru pengajar, suasana kelas), lingkungan masyarakat dan 
lingkungan luar (teman sepermainan, tetangga, keadaan lingkungan rumah). Atau juga dari faktor internal selain kecerdasan emosional dan keaktifan belajar.
$12,35 \%$. Sedangkan $87,65 \%$ sisanya dipengaruhi variabel lain yang tidak diteliti, misalnya lingkungan belajar, fasilitas belajar, motivasi belajar dll Adapun saran dari penelitian ini

Meskipun demikian kecerdasan emosionaadalah

dan keaktifan belajar tetap harus diperhatikan. Agar lebih mudah menerima materi, sebab, keaktifan belajar dan kecerdasan bacalah terlebih dahulu materi kuliah emosional dapat mendukung faktor-faktor lain yang akan disampaikan oleh dosen. yang lebih dominan dan dapat menjadikan siswa. Hendaknya agar tidak lupa setiap meningkatkan prestasi belajarnya. materi kuliah yang baru disampaikan dosen dipelajari lagi dirumah.

\section{KESIMPULAN DAN SARAN}

Berdasarkan hasil penelitian dan pembahasanya, maka dapat diambil kesimpulan sebagai berikut :

1. Keaktifan belajar tidak berpengaruh signifikan terhadap prestasi belajar, Berdasarkan dari hasil pengujian data yang dilakukan secara parsial menunjukan $\mathrm{t}_{\text {tabel }}(1.66)>0,858 \mathrm{t}_{\text {hitung. }}$.

2. Kecerdasan Emosional tidak berpengaruh signifikan terhadap prestasi belajar, Berdasarkan Hasil pengujian data yang dilakukan secara parsial menunjukan $\mathrm{t}_{\text {tabel }}(1.66)>0,091$ $t_{\text {hitung. }}$

3. Variabel Keaktifan belajar mahasiswa memberikan sumbangan efektif 6,25\%. Variabel kecerdasan emosional memberikan sumbangan efektif $6,1 \%$. Jadi total sumbangan efektif adalah
3. Hendaknya mahasiswa yang sering berlatih soal-soal latihan kecerdasan emosional, pelatihan dan seminar wawasan tentang kecerdasan emosional, untuk mengasah kemampuan memecahkan permasalahan dengan baik.

4. Hendaknya mahasiswa mampu mengesampingkan permasalahan pribadi atau mahasiswa mampu mengorganisir emosii dengan baik, sehingga dapat berkosentrasi belajar.

5. Hendaklah dosen memberikan stimulus guna meningkatkan kemampuan mahasiswa dalam memecahkan masalah dengan cara memberikan soal-soal latihan

6. Meskipun ketrampilan mengajar sekarang sudah cukup baik, hendaklah 
lebih ditingkatkan lagi, terutama

ketrampilan pengelolaan kelas

\section{DAFTAR PUSTAKA}

Arikunto, Suharsimi (2012). Dasar-dasar evaluasi pendidikan. Jakarta: Bumi aksara.

Goleman, Daniel. (2012). emotional intelligence. Jakarta: PT Gramedia Pustaka Utama.

Gunawan, Heri (2013). Kurikulum Dan Pembelajaran Pendidikan Agama Islam. Bandung: ALFABETA,cv.

Pratiwi, Winda Erwin (2013). Meningkatkan Keaktifan Belajar Siswa Dalam Pembelajaran IPS Kelas IV Menggunakan Media Gambar Di SDN Banyuraden Gamping tahun ajaran 2012/2013. Yogyakarta : Universitas Negeri Yogyakarta.

Sudaryono. (2011). Metode Penelitian Pendidikan. Dinas Pendidikan Provinsi Banten.

Sudaryono.(2016). Metode Penelitian pendidikan. Jakarta: Prenadia Group.

Sugiyono. (2016). Metode Penelitian. Bandung: ALFABETA.cv

Warsono dan Hariyanto. (2013). Pembelajaran Aktif. Bandung: PT Remaja Rosdakarya.

Wiratna Sujarweni \& Poly Endrayanto. (2012). Statistika Untuk Penelitian. Yogyakarta: Graha Ilmu.

\section{Online}

Andayani, A (2017). Jenis penelitian desriptif. [Online]. Tersedia: http://eprints.ums.ac.id./49282/

Kurnia, M. Khudlaarin Avinita (2012). Pengertian populasi dan sampel serta Teknik Sampling. [Online]. Tersedia http://eprints.uny.ac.id/9783/3.[4 juni 2018] .

Rose, M (2012). Faktor-faktor yang mempengaruhi keaktifan. [Online]. Tersedia: http://eprints.uny.ac.id./8772/3/. [28 desember 2017] 